\title{
A Patient with Recurrent Breast Cancer Showing Long-Term Survival after Developing Pericardial Effusion and Cardiac Tamponade Caused by Carcinomatous Pericarditis
}

\author{
Hirokuni Ikeda Yuichiro Kikawa Yoshihiko Nakamoto Masahiko Takeo Mistuo Yamamoto \\ Department of Surgery, Kobe City Hospital Organization Kobe City Center West Hospital, Kobe Nagata-ku, Hyogo, Japan
}

\section{Keywords}

Breast cancer - Carcinomatous pericarditis · Pericardial effusion - Cardiac tamponade - Thoracoscopic pericardial window

\section{Summary}

Background: Malignant pericardial effusion caused by carcinomatous pericarditis is a complication of advanced malignancy. Breast cancer is the second most important cause of malignant pericardial effusion. Malignant pericardial effusion is the end stage of breast cancer, and the prognosis is very poor. Pericardial effusion may cause cardiac tamponade and sudden death if it is not controlled properly. There is a debate on which is the best method to control pericardial effusion. Case Report: We describe the clinical course of a 55-year-old woman with recurrent breast cancer, pericardial effusion, and cardiac tamponade caused by carcinomatous pericarditis. Thoracoscopic pericardial window was performed to control the pericardial effusion. The patient survived for about 5 years after being diagnosed with pericardial metastases. Conclusion: The observed long-term survival in such a patient with the development of pericardial effusions and cardiac tamponade caused by carcinomatous pericarditis attributable to breast cancer is rare. Thoracoscopic pericardial window was effective in controlling the pericardial effusion.

\section{Introduction}

Malignant pericardial effusion caused by carcinomatous pericarditis is a complication of advanced malignancy; however, this type of pericardial effusion is relatively uncommon.

\author{
Schlüsselwörter \\ Mammakarzinom · Karzinomatöse Perikarditis . \\ Perikarderguss · Herztamponade · Thorakoskopische \\ Fenestrierung des Perikards
}

\section{Zusammenfassung}

Hintergrund: Der maligne Perikarderguss verursacht durch karzinomatöse Perikarditis ist eine Komplikation fortgeschrittener Tumorerkrankungen. Das Mammakarzinom ist die zweithäufigste Ursache des malignen Perikardergusses. Der Perikarderguss tritt im Endstadium von Brustkrebs auf und ist mit einer ungünstigen Prognose verbunden. Perikardergüsse können bei unzureichender Behandlung zur Herztamponade und plötzlichem Tod führen. Was die beste Behandlungsmethode für Perikardergüsse ist, wird derzeit kontrovers diskutiert. Fallbericht: Wir beschreiben den klinischen Verlauf einer 55-jährigen Patientin mit rezidiviertem Mammakarzinom, Perikarderguss und Herztamponade verursacht durch karzinomatöse Perikarditis. Der Perikarderguss wurde mittels thorakoskopischer Fenestrierung des Perikards behandelt. Die Patientin überlebte nach Diagnose ihrer Perikardmetastasen ca. 5 Jahre. Schlussfolgerung: Das bei unserer Patientin beobachtete Langzeitüberleben ist für Patienten mit Perikarderguss und Herztamponade verursacht durch karzinomatöse Perikarditis infolge eines Mammakarzinoms selten. Mittels der thorakoskopischen Fenestrierung des Perikards konnte der Perikarderguss effektiv kontrolliert werden.

Breast cancer is the second most important cause of malignant pericardial effusion [1-3]. In an autopsy series of patients with breast cancer, pericardial disease was reported in $19 \%$ of the patients [3]. Malignant pericardial effusion is the end stage of breast cancer, and the prognosis is very poor $[1,2,4]$.

\section{KARGER \\ Fax +497614520714 \\ Information@Karger.com}

www.karger.com (c) 2013 S. Karger GmbH, Freiburg

$1661-3791 / 13 / 0081-0071 \$ 38.00 / 0$

Accessible online at:

www.karger.com/brc 
Pericardial effusion may cause cardiac tamponade and sudden death if it is not controlled properly. Carcinomatous pericarditis cannot be cured, and therefore symptomatic relief may be the most important aspect of successful treatment for patient's quality of life. According to the guidelines of the European Society of Cardiology, 3 procedures are commonly used to control pericardial effusion: pericardiocentesis, intrapericardial therapy, and surgery [5]. We report a case of a breast cancer patient who survived for 5 years after developing pericardial effusion and cardiac tamponade caused by carcinomatous pericarditis. Thoracoscopic pericardial window was performed to control the pericardial effusion.

\section{Case Report}

In May 2006, a 55-year-old woman with a chief complaint of dyspnea was admitted to our hospital. The patient's medical history was significant. In January 2004, she had undergone surgery to preserve her left breast and axillary dissection to treat stage IIA breast cancer. The statuses of estrogen receptor, progesterone receptor, and human epidermal growth factor receptor 2 were negative. After surgery, she received radiation therapy but rejected adjuvant chemotherapy (adriamycin and cyclophosphamide) because of its adverse effects.

On admission, the patient had a moderate degree of respiratory distress, and her oxygen saturation was $94 \%$ in room air. Jugular venous distension was observed. Moist rales were heard in both lungs on auscultation. Her blood pressure was $110 / 70 \mathrm{mmHg}$, and her heart rate was regular and about 110 beats/min. Electrocardiography revealed low voltage QRS complexes, and chest radiography showed an enlarged cardiac shadow and bilateral pleural effusion (fig. 1a). Computed tomography (CT) showed a large amount of pericardial effusion and bilateral pleural effusion (fig. 1b). Echocardiography also showed a large amount of pericardial effusion. Therefore, the patient was diagnosed with cardiac tamponade; pericardiocentesis was immediately performed, and approximately $850 \mathrm{ml}$ of sanguineous fluid was drained. Cytological examination of the sanguineous fluid was class 5 , and the patient was suspected to have carcinomatous pericarditis associated with metastatic breast cancer. Her general condition improved after undergoing pericardiocentesis. To control the pericardial effusion, thoracoscopic pericardial window was performed on the left side of the heart (fig. 2). Intraoperative findings showed no pulmonary metastasis and pleural dissemination. A $3 \times 4-\mathrm{cm}$ region of the pericardium was resected using a thoracoscopic approach. The patient was diagnosed with carcinomatous pericarditis associated with metastatic breast cancer on the basis of the histopathological examination of the specimen.
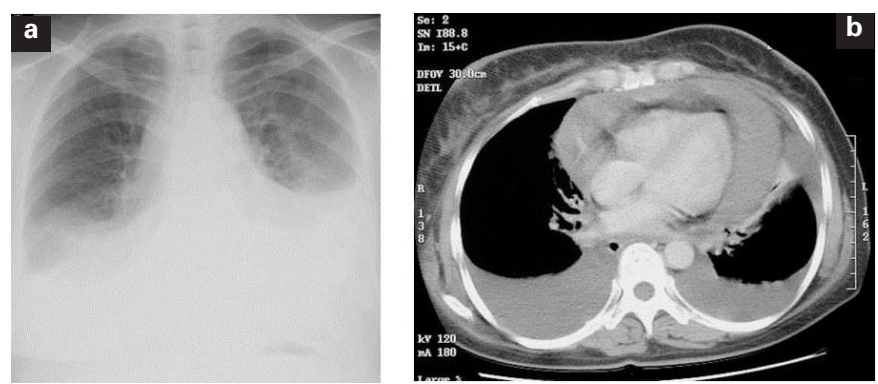

Fig. 1. a Chest radiograph showing an enlarged cardiac shadow and bilateral pleural effusion. b Computed tomography showing a large amount of pericardial effusion and bilateral pleural effusion.

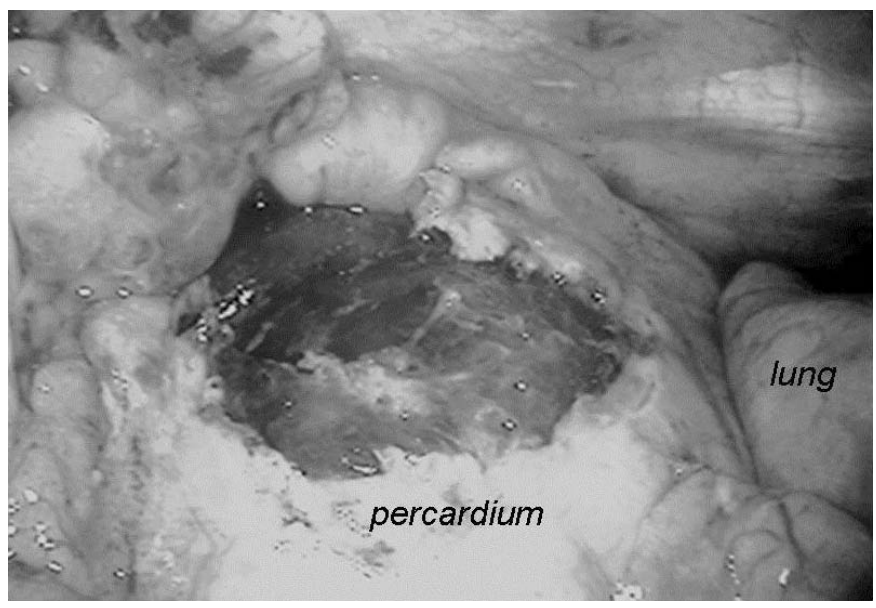

Fig. 2. Thoracoscopic pericardial window was performed on the left side of the heart. A $3 \times 4-\mathrm{cm}$ region of the pericardium was resected using a thoracoscopic approach.
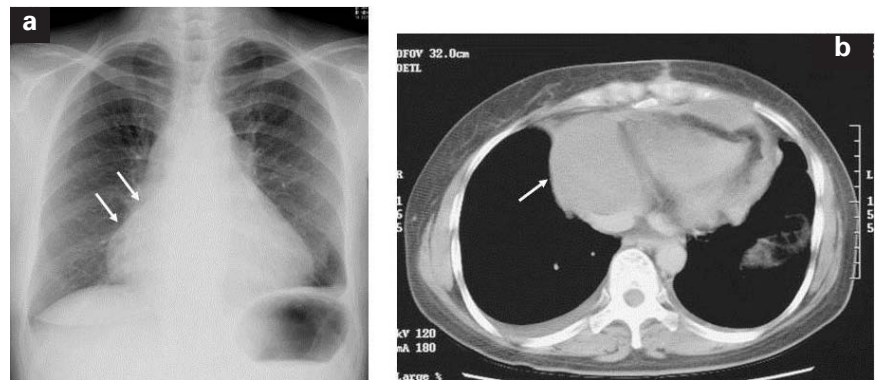

Fig. 3. a Chest radiograph showing an enlarged cardiac shadow especially on the right side of the heart. b Computed tomography showing localized pericardial effusion on right side of the heart.

At this time, no metastatic lesions were observed in the important organs other than the pericardium. The patient received 6 cycles of chemotherapy with 5-fluorouracil, epirubicin, and cyclophosphamide. In January 2007, she experienced dyspnea, and chest radiography showed an enlarged cardiac shadow (fig. 3a). CT detected pericardial effusion in the right side of the heart (fig. 3b). Pericardiocentesis and thoracoscopic pericardial fenestration was performed on the right side of the heart. After the operation, she was treated with weekly paclitaxel.

In August 2007, metastasis was observed on her left breast. She was treated with capecitabine and cyclophosphamide for 5 months, weekly paclitaxel for 6 months, triweekly docetaxel for 7 months, vinorelbine for 5 months, irinotecan for 10 months, gemcitabine alone for 2 months, and a combination of gemcitabine and paclitaxel for 3 months. In addition to treatment with several chemotherapeutic drugs, she underwent radiotherapy and local excision. In February 2011, she died because of lymphangitic carcinomatosis of the lung. She survived for about 5 years after being diagnosed with pericardial metastases, and no recurrence of pericardial effusion was observed after the last operation.

\section{Discussion}

The prognosis of carcinomatous pericarditis associated with breast cancer is very poor $[1,2]$. In our case, the patient survived for 5 years after developing pericardial effusions and 
cardiac tamponade caused by carcinomatous pericarditis. We believe that she showed a long survival period. We think that the reasons for the patient's long survival were absence of metastasis in the organs other than the pericardium and a positive response to chemotherapy. The patient rejected adjuvant therapy despite it being very effective in suppressing the recurrence of breast cancer. If she had received appropriate adjuvant therapy, she could have survived longer.

Patients with malignant pericardial effusion disease have almost no chance of being cured; therefore, symptomatic relief is very important. There is a debate regarding the best treatment to control pericardial effusion [6-9]. In our case, we performed pericardial window by using a videothoracoscope and obtained a successful outcome. Our patient showed an atypical recurrence of pericardial effusion in only the right side of the heart after the initial operation, but there was no recurrence after the second operation. We encourage the use of pericardial window because it is minimally invasive and affords good control of pericardial effusion.

The survival period of breast cancer patients will become longer, and opportunities to treat pericardial metastases and pericardial effusion will increase with the progress in breast cancer treatments such as chemotherapy, endocrine therapy, or molecular-targeted therapy. In selecting the mode of treatment, we should consider not only the patient's survival but also improvements in the quality of life.

\section{Conclusion}

Carcinomatous pericarditis associated with breast cancer shows a poor prognosis. We reported a case of long-term survival in a patient with recurrent breast cancer after developing pericardial effusion and cardiac tamponade caused by carcinomatous pericarditis. Thoracoscopic pericardial window was effective in controlling the pericardial effusion.

\section{Disclosure Statement}

The authors report no conflict of interests.

\section{References}

${ }_{1}$ Gornik HL, Gerhard-Herman M, Beckman JA: Abnormal cytology predicts poor prognosis in cancer patients with pericardial effusion. J Clin Oncol 2005;23:5211-5216.

2 Tsang TS, Seward JB, Barnes ME, Bailey KR, Sinak LJ, Urban LH, Hayes SN: Outcomes of primary and secondary treatment of pericardia effusion in patients with malignancy. Mayo Clin Proc 2000;75:248-253.

3 Abraham KP, Reddy V, Gattuso P: Neoplasms metastatic to the heart: review of 3314 consecutive autopsies. Am J Cardiovasc Pathol 1990;3:195-198.
4 Pokieser W, Cassik P, Fischer G, Vesely M, Ulrich W, Peters-Engl C: Malignant pleural and pericardial effusion in invasive breast cancer: impact of the site of the primary tumor. Breast Cancer Res Treat 2004;83:139-142.

5 Maisch B, Seferović PM, Ristić AD, Erbel R, Rienmüller R, Adler Y, Tomkowski WZ, Thiene G, Yacoub MH: Task Force on the Diagnosis and Management of Pericardial Diseases of the European Society of Cardiology: Guidelines on the diagnosis and management of pericardial diseases executive summary. Eur Heart J 2004;25:587-610.
6 Laham RJ, Cohen DJ, Kuntz RE, Baim DS, Lorell $\mathrm{BH}$, Simons M: Pericardial effusion in patients with cancer: outcome with contemporary management strategies. Heart 1996;75:67-71.

7 Fibla JJ, Molins L, Mier JM, Vidal G: Pericardial window by videothoracoscope in the treatment of pericardial effusion and tamponade. Cir Esp 2008; 83:145-148.

8 Swanepoel E, Apffelstaedt JP: Malignant pericardial effusion in breast cancer: terminal event or treatable complication? J Surg Oncol 1997;64:308-311.

9 Buck M, Ingle JN, Giuliani ER, Gordon JR, Therneau TM: Pericardial effusion in women with breast cancer. Cancer 1987;60:263-269. 